\title{
Modul Bina Diri Tunagrahita untuk Meningkatkan Keterampilan Mengajar Guru Inklusif
}

\author{
Akrim Ilma Mufidah, Sinta Yuni Susilawati \\ Universitas Negeri Malang \\ E-mail: $\underline{\text { mufidahilmaakrim@gmail.com }}$
}

\begin{abstract}
Abstrak: Keefektifan Modul Bina Diri untuk Meningkatkan Keterampilan Mengajar di Sekolah Inklusif. Tujuan penelitian ini untuk mengetahui keefektifan modul bina diri untuk meningkatkan keterampilan guru mengajar bina diri di sekolah inklusif. Metode penelitian menggunakan Borg and Gall yang memiliki sepuluh tahap. Dalam penelitian ini penulis mengadaptasi menjadi tujuh tahap. Hasil penelitian menunjukkan modul bina diri anak tunagrahita efektif digunakan untuk meningkatkan keterampilan guru mengajar.
\end{abstract}

Kata kunci: Modul, Bina Diri, Tunagrahita, Keterampilan Mengajar, Sekolah Inklusif

\begin{abstract}
Effectiveness of Self-Development Modules to Improve Teaching Skills in Inclusive Schools. The purpose of this study is to improve the skills of teachers in self-development in inclusive schools. This research uses the Borg and Gall development method you which has ten stages. The author's study adapted into seven stages. The results showed that the module of effective mental retardation was used to improve the skills of teaching teachers.
\end{abstract}

Keywords: Modules, Self Development, Mentally impaired, Teaching Skills, Inclusive Schools

Pada umumnya peserta didik tunagrahita lebih banyak bergantung pada orang tua dan orang-orang disekitarya. Hal tersebut disebabkan oleh hambatan intelektual dibawah rata-rata, perilaku yang kurang adaptif, keterbatasan keterampilan berkomunikasi dan keterbatasan dalam akademik. Hambatan peserta didik tunagrahita dipandang anak yang tidak dapat menolong diri sendiri, mengalami kesulitan dalam berinteraksi sosial sehingga diperlukan pendidikan yang terprogram yang berlangsung terus menerus dalam pembiasaan kehidupan sehari-hari sehingga peserta didik tunagrahita hidup mandiri dan berperilaku sesuai dengan norma dan aturan (Direktorat PKLK, 2016).

Gunahardi dan Maryadi (2011) menjelaskan, program bina diri bertujuan agar anak tunagrahita dapat mengurus dirinya sendiri, bersosialisasi dan berkomunikasi dengan lingkungan serta melakukan pekerjaan sehari-hari secara mandiri. Pendapat tersebut sesui dengan pendapat Tri, dkk (2017), bina diri merupakan aktivitas yang dilakukan dalam kehidupan sehari-hari seperti makan, berpakaian dan berpindah tempat tanpa membutuhkan bantuan orang lain. Pelaksanaan program bina diri dapat tercapai secara optimal apabila sekolah bekerja sama dengan orang tua dan masyarakat. Orang tua berperan membiasakan anak mandiri melalui kegiatan sehari-hari seperti mengurus diri, menjaga kebersihan diri dan membantu mengurus rumah.

Anak tunagrahita belajar menyesuaikan diri dengan norma, nilai dan budaya yang berlaku di masyarakat. Sekolah sebagai lembaga yang melaksanakan kurikulum bina diri perlu memiliki guru yang mempunyai kompetensi yang dapat memberikan layanan pendidikan peserta didik tunagrahita. Garnida
(2016) menjelaskan, "Kecermatan dan keseksamaan dalam melaksanakan kegiatan bina diri bagi anak tunagrahita sangat dituntut untuk dimiliki oleh guru yang mengajar di setiap Sekolah Luar Biasa dan Sekolah inklusif".

Tunagrahita adalah anak yang berhak mendapatkan pendidikan yang layak dan bermutu baik di SLB maupun di sekolah inklusif. Peraturan Gubernur Jawa Timur Pasal 7 No. 6 tahun 2011 pasal 7 ayat 1 menjelaskan "Sarana dan prasarana bagi peserta didik berkebutuhan khusus serta memperhatikan akesebilitas dan/atau alat sesuai kebutuhan peserta didik". Sarana dan prasarana di sekolah inklusif merupakan tanggung jawab pemerintah pusat, pemerintah daerah, orang tua dan masyarakat serta komite sekolah. Sarana dan prasana tersebut digunakan sebagai penunjang untuk mengembangkan potensi peserta didik luar biasa. Peserta didik tunagrahita membutuhkan sarana dan prasarana yang aksebilitas sesuai dengan potensi yang dimilikinya. Sarana dan prasarana yang dibutuhkan untuk bina diri peserta didik tunagrahita yaitu alat peraga bina diri, ruangan latihan bina diri dan modul pembelajaran.

Modul pembelajaran adalah sebuah bahan ajar yang disusun menggunakan bahasa yang mudah dipahami sehingga peserta pembelajaran dapat belajar secara mandiri tanpa membutuhkan seorang fasilitator. Ditjen PMPTK (2008) menjelaskan, "modul yaitu buku cetak yang dirancang agar dapat dipelajari secara mandiri oleh peserta pembelajaran." Modul dapat digunakan secara mandiri oleh guru sehingga lebih menghemat waktu dan biaya. Sebagian besar guru di SDN Sumbersari II bukan belatar belakang pendidikan khusus sehingga membutuhkan modul sebagai sarana untuk belajar tentang bina diri anak tunagrahita. 
Keterbatasan waktu, ruang dan biaya memungkinkan guru untuk belajar menggunakan modul. Guru dapat menilai kemampuan hasil belajar melalui latihan soal. Modul dapat meningkatkan kompetensi guru dan meningkatkan pembelajaran bina diri yang efektif dan berkualitas. Berikut ini studi pendahuluan peneliti di SDN Sumbersari II. Pertama, program bina diri anak tunagrahita sudah ada, namun belum berjalan lancar karena keterbatasan jam pelajaran di sekolah sehingga lebih memprioritaskan pemberian materi akademik. Dahulu saat menjadi sekolah rintisan inklusif, memiliki dana untuk mengadakan program bina diri. Sedangkan saat ini sekolah sudah mandiri sehingga belum memiliki cukup dana untuk mengembangkan pembelajaan bina diri. Akibatnya GPK menyediakan alat dan bahan yang sederhana untuk pembelajaran bina diri.

Kedua, prespektif pemikiran guru kelas terhadap pogram bina diri. Guru kelas berpikir program bina diri merupakan tugas GPK. Sedangkan harapan dari GPK semua guru dan orang tua bekerja sama dalam pelaksanaan program bina diri. Dari kondisi tersebut, GPK mengalami kendala untuk mengatur jadwal pembelajaran bina diri dengan jadwal pelajaran dikelas. Jadwal pembelajaran kurikulam K13 sampai jam 3 sore, sedangkan apabila ada jam tambahan secara fisik anak sudah tidak mampu. Apabila pembelajaran bina diri dilaksanakan saat jam pelajaran, peserta didik tunagrahita akan tertinggal materi pelajaran di kelas. Pernyataan tersebut sesuai dengan temuan penelitian Wulandari, Susilawati \& Kustiawan (2019), kendala pelaksanaan program bina diri memasak bertepatan dengan kegiatan reguler sekolah seeperti try out dan pensi. Harapan dari GPK sekolah menyediakan modul bina diri sehingga semua guru dapat bekerjasama melaksanakan program bina diri. Modul yang sudah dipatenkan baku khusus anak tunagrahita sehingga GPK tidak perlu memodifkasi pembelajaran.

Berdasarkan hasil wawancara dengan GPK, sekolah belum menyediakan modul, apabila GPK menyusun modul harus belajar terlebih dahulu dan membutuhkan lebih banyak waktu. Selama ini GPK merangkum materi berdasarkan kelas I, II, III dan kelas IV, V dan VI. Kondisi tersebut dikarenakan ada 13 anak tunagrahita dengan berbagai macam karakteristik dan GPK tidak sempat membuat pembelajaran individual.

Kegiatan pembelajaran bina diri yang sudah berjalan yaitu membuat keterampilan origami, daur ulang daun dan botol bekas. Selain itu ada kegiatan memakai baju, menyetrika baju, melipat baju. GPK menentukan tujuan pembelajaran dengan cara mengamati kondisi anak dan merencanakan kegiatan apa yang sesuai dengan kondisi anak. Hasil wawancara dengan guru kelas, mereka sangat mendukung jika ada program bina diri yang melibatkan guru kelas. Guru kelas belum pernah mendapatkan pelatihan, sosialisasi atau seminar tentang bina diri. Guru kelas sangat antusias dan mendukung saat peneliti menawarkan modul bina diri tunagrahita di SDN Sumbersari II.
Selain itu peneliti juga melakukan observasi untuk mengalisis kebutuhan siswa. Siswa tunagrahita disekolah tersebut belum memiliki kemandirian mengurus dirinya sendiri, contohnya penggunaan toilet dan sikat gigi

Kebutuhan modul bina diri di sekolah inkluisif menjadi alasan utama untuk penulis mengembangkan modul pembelajaran. Dengan adanya modul bina diri dimaksudkan agar guru memiliki kompetensi bina diri sehingga anak tunagrahita di sekolah inklusif memperoleh pembelajaran bina diri.

\section{METODE}

Penelitian dan pengembangan ini menggunakan pendekatan Research Development (R\&D) dari Borg and Gall (Silalahi, 2017). Adapun tahap-tahap pengembangan dari Borg and Gall (1987) adalah (1) Research And Information Collecting, (2) Planning, (3) Develop Peliminary Form Of Product, (4) Preliminary Field Testing, (5) Main Product Revision, (6) Main Field Testing, (7) Operational Product Revision, (8) Operational Field Testing, (9) Final Product Revision, (10) Dissemination And Implementation. Tahap-tahap dalam

penelitian dan pengembangan tidak harus harus diikuti secara lengkap. Menurut Gooch dalam Hasyim (2016), penelitian ini perlu disederhanakan menjadi tujuh tahapan. Tahap-tahap tersebut yaitu: (1) penelitian dan pengumpulan data; (2) perencanaan; (3) pengembangan desain produk awal; (4) validasi produk; (5) merevisi hasil uji coba; (6) uji coba lapangan; dan (7) penyempurnaan produk akhir.

Subjek penelitian ini menggunakan siswa Tunagahita kelas II SDN Sumbersari II yang belum dapat menggunakan kaos kaki dan Guru Pembimbing Khusus. Subjek in dipilih karena siswa tersebut belum dapat memakai kaos kaki dan membuthkan pembelajaran bina diri. Teknik pengumpulan data yang dilakukan adalah 1) wawancara yang bertujuan untuk memperoleh informasi awal tentang kebutuhan yang ada di lapangan, 2) tes yang bertujuan untuk mengetahui keefektifan modul. Teknik analsis data digunakan untuk mengukur skor hasil tes kinerja siswa dan hasil tes pengetahuan guru yang diadpsi dari (Akbar):

\section{$\mathrm{P}=\Sigma \mathrm{x} / \Sigma \mathrm{xi} \times 100 \%$}

Selanjutnya hasil dari nilai tersebut digabungkan ke dalam rumus berikut:

\section{$\mathrm{P}=($ Nilai1 + Nilai2 $) / 2 \quad \mathrm{X} 100 \%$}

Selanjutnya untuk keefektifan produk dalam pembelajaran mengacu pada SKM (Standard Kelulusan Minimal) adalah 75. Hasil dari perhitungan tersebut kemudian diinterpretasikan ke dalam kriteria keefektifan yang diadaptasi dari Akbar (2017). 


\section{HASIL DAN PEMBAHASAN}

\section{Hasil}

Hasil wawancara studi lapangan yang dilakukan kepada guru pembimbing khusus di SDN Sumbersari II diperoleh bahwa, 1) sekolah belum menyediakan sarana prasarana bina diri tunagrahita seperti modul, 2) jadwal pembelajaran bina diri yang terbentur dengan kegiatan di kelas sehingga program bina diri belum berjalan lancar, 3) keterbatasan dana yang dimiliki sekolah untuk menyediakan sarana dan prasarana bina diri.

Berdasarkan hasil validasi ahli media diperoleh presentase 92,5\% termasuk pada kategori sangat valid atau dapat digunakan. Hasil validasi penilaian ahli materi diperoleh hasil $86,5 \%$ termasuk pada kategori sangat valid atau dapat digunakan. Hasil analisis dan pengolahan data validasi ahli bahasa diperoleh hasil $98 \%$ yang dapat dikategorikan sangat valid atau dapat digunakan. Hasil validasi ahli praktisi diperoleh hasil $89,5 \%$ yang dapat dikategorikan sangat valid atau dapat digunakan.

Uji coba dilakukan saat pembelajaran bina diri tunagrahita menggunakan subjek satu siswa tunaagrahita dan satu guru pembimbing khusus. Uji coba dilakukan untuk mengetahui efektifitas modul bina bina diri tunagrahita. Uji coba dilakukan berdasarkan penilaian kinerja terhadap hasil belajar siswa setelah mendapatkan pembelajaran menggunakan kaos kaki (post test). Selain itu ada penilaian pengetahuan untuk guru setelah pembelajaran bina diri menggunakan modul (post test).

Dari hasil uji efektivitas modul dapat dijelaskan skor penilaian tes kinerja siswa $79,1 \%$ sedangkan hasil penilaian tes pengetahuan guru adalah $90 \%$. Skor tersebut kemudia dicari skor rata-rata yang diperoleh hasil $84,5 \%$. Hasil rata-rata skor tersebut menunjukkan modul bina diri sangat efektif digunakan.

\section{Pembahasan}

Penelitian ini berangkat dari permasalahan anak tunagrahita di sekolah inklusif yang belum memiliki keterampilan bina diri dan sarana prasarna seperti modul yang terbatas. Darmiatun (2013) memberikan penjelasan modul merupakan bahan ajar yang disusun lengkap dan sistematis yang terdapat materi yang digunakan untuk membantu peserta pembelajaran mencapai tujuan belajar yang spesifik. Modul bina diri merupakan modul yang digunakan guru untuk menyusun program pembelajaran bina diri. Materi dalam modul ini disusun secara lengkap dan sistematis, terdiri dari dua bagian yaitu konsep bina diri tunagrahita dan proses penyusunan program pembelajaran bina diri.

Keunggulan modul menurut Mulyasa (2009) yaitu modul dipelajari secara mandiri oleh peserta pembelajaran yang disesuiakan dengan kemampuanya, serta ada tujuan dan evalusi. Saat guru menggunkan modul ini, dapat mempelajari materi dan mengukur hasil belajarnya melalui evaluasi. Modul dirancang khusus untuk pembelajaran mandiri, khususnya untuk memenuhi kebutuhan guru di sekolah inklusi. Dengan terakomodasi kebutuhan guru diharapkan dapat meningkatkan keterampilan mengajar, sehingga pembelajaran bina diri menjadi efektif. Selain itu modul ini mempunyai desain buku dengan layout menarik dan menggunakan kertas glossy.

Selanjutnya Mulyasa (2009) juga menjelaskan kelemahan modul yaitu penyusunan modul membutuhkan keahlian tertentu, sukar menentukan proses evaluasi karena setiap pembelajaran memiliki kemampuan yang berbeda untuk menyelesaikan modul dan biaya yang digunakan untuk memperoleh modul cukup mahal. Kelemahan modul bina diri anak tungarahita ini adalah proses penyusunan modul membutuhkan waktu yang cukup lama karena materi yang disajikan banyak dan saling berkaitan. Selain itu, jika modul ini didesain kurang menarik, kemungkinan pembaca akan mudah bosan

\section{KESIMPULAN DAN SARAN}

\section{Kesimpulan}

Hasil validasi produk diperoleh skor rata-rata $90 \%$. Jika mengacu pada kriteria kevalidan, skor tersebut termasuk dalam kriteria kevalidan sangat valid. Hasil uji coba diperoleh hasil $84,5 \%$. Jika melihat kriteria keefektifan produk, maka hasil uji coba individu masuk dalam kategori tinggi atan efektif.

\section{Saran}

Saran yang diajukan peneliti ditinjau dari pemanfaatkan diharapkan modul, dapat digunakan sebagai bahan ajar bagi guru dalam pembelajaran diri. Saran pengembangan lebih lanjut, dapat dilakukan melalui penelitian kuantitatif dengan memanfaatkan bina diri. Tujuannya untuk mengetahui apakah ada pengaruh modul terhadap peningkatan kemampuan siswa tunagrahita dalam pembelajaran bina diri. Selain itu, sebaiknya validator lebih dari satu orang agar produk yang dihasilkan lebih layak dan sempurna untuk digunakan dalam pembelajaran.

\section{DAFTAR PUSTAKA}

Akbar, S. D. (2013). Instrumen perangkat pembelajaran.

Darmiatun, S. (2013). Menyusun Modul Bahan Ajar Untuk Persiapan Guru Dalam Mengajar. Yogyakarta: Gava Media. 
Garnida, D. (2016). Modul Guru Pembelajar SLB Tunagrahita Kelompok Kompetensi A. Bandung: PPPPTK TK dan PLB.

Gunahardi \& Maryadi. 2011. Modul PLPG Pendidikan Luar Biasa Pendalaman Materi. Surakarta: FKIP UNS.

Hasyim, A. (2016). Metode penelitian dan pengembangan di Sekolah. Yogyakarta: media akademi.

Indonesia, P. M. P. N. R. Nomor 70 Tahun 2009 tentang Pendidikan Inklusif bagi Peserta Didik yang Memiliki Kelainan dan Memiliki Potensi Kecerdasan dan/atau Bakat Istimewa. 2009. Jakarta: Sekretariat Negara.

Kependidikan,D.T., MUTU,D.J.P., KEPENDIDIKAN, P. D. T., \& NASIONAL, D. P. (2008). Penulisan Modul. Jakarta: Depdiknas

Mulayasa, E. (2006). Kurikulum Yang Disempurnakan Pengembangan Standar Kompetensi dan Kompetensi Dasar. Bandung: PT Remaja Rosdakarya.

Nasional, D. P. (2006). Pedoman memilih dan menyusun bahan ajar. Jakarta: Depdiknas.
Nomor, P. G. J. T. (6). Tahun 2011 tentang Penyelenggaraan Pendidikan Inklusif Provinsi Jawa Timur. 2011. Surabaya: Berita Daerah Provinsi Jawa Timur.

PKLK, D.P.(2016). ModulPelatihan KurikulumKhusus Tahun 2013 Materi Program Pengembangan Diri Bagi Peserta Didik Tunagrahita. Jakarta: Kemendikbud.

Silalahi, A. (2018). Development Research (Penelitian Pengembangan) Dan Research \& Development (Penelitian \& Pengembangan) Dalam Bidang Pendidikan/Pembelajaran.

Tri, Y. D. Y., Cipta, N. A. N., Budhi, B. W., \& Sahadi, S. H. (2017, November). Activity daily living (ADL) of young people with intellectual disabilities. In International Conference on Diversity and Disability Inclusion in Muslim Societies (ICDDIMS 2017). Atlantis Press, 40-43.

Wulandari, L. M. Susilawati, Y. S. \& Kustiawan, U. (2019). Pelaksanaan Program Bina Diri bagi Siswa Berkebutuhan Khusus di Sekolah Inklusi. Jurnal Ortopedegogia. 5(1), 44-49. 